\title{
Photooxidative Degradation of QTX (a Thioxanthone Derivative)
}

\author{
Miguel G. Neumann, ${ }^{* a}$ Carla C. Schmitt, ${ }^{a}$ Alessandra L. Poli, ${ }^{a}$ \\ José Carlos Netto-Ferreira ${ }^{b}$ and Josy A. Osajima ${ }^{a}$ \\ ${ }^{a}$ Instituto de Química de São Carlos, Universidade de São Paulo, CP 780, \\ 13560-970 São Carlos-SP, Brazil \\ ${ }^{b}$ Departamento de Química, Instituto de Ciências Exatas, Universidade Federal Rural do \\ Rio de Janeiro, 23851-970 Seropédica-RJ, Brazil
}

\begin{abstract}
Foi estudada a degradação fotooxidativa de QTX (cloreto de 2-hidroxi-3-(3,4-dimetil-9-oxo9H-tioxanton-2-iloxi)-N,N,N-trimetil-1-propano) em solução aquosa. Os produtos resultantes foram caracterizados por HPLC/ESI-MS e a fotodegradação do corante foi acompanhada por espectroscopia de absorção. O corante apresenta duas bandas em 273 e 402 nm, que decrescem durante a irradiação, enquanto que aparece uma banda na região de 310-350 nm, típica do QTX oxidado. Novos picos devidos aos fotoprodutos da degradação de QTX foram observados por cromatografia e identificados por espectrometria de massa. Os picos em $\mathrm{m} / \mathrm{z}$ 388, 420 e 270 correspondem a fotoprodutos, e o de $\mathrm{m} / \mathrm{z}, 372$ é atribuído ao QTX. O pico de $\mathrm{m} / \mathrm{z}, 388$ corresponde à formação de um grupo sulfóxido e o de $\mathrm{m} / \mathrm{z}, 420$ sugere a formação de uma sulfona com uma hidroxila no grupo metila. O pico de $\mathrm{m} / z, 270$ sugere que o oxigênio reage com QTX abstraindo um hidrogênio do carbono ligado à hidroxila, simultaneamente à eliminação de um grupo amino.
\end{abstract}

The photooxidative degradation of QTX (2-hydroxy-3-(3,4-dimethyl-9-oxo-9H-thioxanthen2-yloxy)-N,N,N-trimethyl-1-propanium chloride) has been investigated and photoproducts from QTX degradation in aqueous solution were characterized using HPLC/ESI-MS. The photooxidation of the dye was monitored by electronic absorption spectroscopy. The spectrum of the dye shows bands at 273 and $402 \mathrm{~nm}$. During irradiation, the intensity of these bands decreases together with the appearance of a band at 310-340 nm, typical of oxidized QTX. The chromatograms show the presence of new peaks due to photoproducts of QTX degradation that were identified by mass spectroscopy. The peaks at $\mathrm{m} / \mathrm{z}, 388,420$ and 270 were attributed to photoproducts, whereas the peak at $\mathrm{m} / \mathrm{z} 372$ is due to QTX. The peak at $\mathrm{m} / \mathrm{z}, 388$ corresponds to the formation of a sulfoxide group and that at $\mathrm{m} / z, 420$ suggested the formation of a sulfone with a hydroxyl on the methyl group. The peak at $m / z, 270$ suggests that oxygen reacts with QTX abstracting a hydrogen atom from the carbon bonded the hydroxyl, together with the release of the amino group.

Keywords: substituted thioxanthones, photodegradation, QTX, photopolymerization, photosensitizers, photoinitiators

\section{Introduction}

Compounds based on thioxanthones are among the most used photoinitiators for free radical polymerization. ${ }^{1,2}$ The photophysics and the interaction of the excited states of substituted thioxanthone were studied to predict their behaviour as photoinitiators in photopolymerization systems. ${ }^{3}$ The triplet-triplet and transient absorption of non-substituted and substituted thioxanthones were studied in different solvents and it was found that the amount of

*e-mail: neumann@iqsc.usp.br triplet species and radicals depended on the solvent as well as on the substituents on the aromatic ring. ${ }^{4}$ It is well known that the activity as photoinitiators of these compounds is based on radical formation through the interaction of the thioxanthone (TX) triplet excited state with tertiary amines. ${ }^{3.5}$ QTX is a useful photoinitiator of polymerization in aqueous solution and can be used in various applications, as for example, in dental resins. ${ }^{6}$

Various organic dyes are used as photoinitiators for photopolymerization as well as sensitizers for the photodegradation of polymers. ${ }^{7-9}$ In a previous work, thioxanthone was used as photosensitizer for the degradation 
of poly(alkyl methacrylate) films. The polymer degradation mechanism involved the initial formation of macroradicals originated by the abstraction of hydrogen from the polymer chain by the triplet state of thioxanthone. ${ }^{10}$ However, there are few reports about the oxidation of thioxanthones themselves. ${ }^{11}$ The irradiation of organic dyes leads to reactive electronic excited states. In the presence of oxygen, these transients will react to form reactive oxygen species, that initiate the photodegradation chain mechanism which may involve the participation of singlet oxygen and superoxide anion as the most reactive oxygen species. ${ }^{12}$

Recently, photocatalytic and photolytic degradation of various dye solutions have been suggested in the literature. ${ }^{13-15}$

The photooxidative degradation of QTX (2-hydroxy-3(3,4-dimethyl-9-oxo-9H-thioxanthen-2-yloxy)-N,N,Ntrimethyl-1-propanium chloride, Scheme 1) in aqueous solution was studied in this work, and the degradation photoproducts were analyzed and characterized by HPLC/ESI-MS.<smiles>Cc1c(OCC(O)C[N+](C)(C)C)cc2c(=O)c3ccccc3sc2c1C</smiles>

Scheme 1. QTX.

\section{Experimental}

To determine the molar extinction coefficient for ground state QTX, spectra were collected in the concentration range of $3.0 \times 10^{-5}$ to $1.0 \times 10^{-4} \mathrm{~mol} \mathrm{~L}^{-1}$, from which a $\varepsilon$-value of $4.77 \times 10^{3} \mathrm{~L} \mathrm{~mol}^{-1} \mathrm{~cm}^{-1}$ at $402 \mathrm{~nm}$, in aqueous solution, was obtained.

\section{Sample preparation}

Solutions containing QTX $3 \times 10^{-5}, 5 \times 10^{-5}, 7 \times 10^{-5}$ and $1 \times 10^{-4} \mathrm{~mol} \mathrm{~L}^{-1}$ were prepared in Milli Q water. The solutions were placed in Pyrex test tubes and the photodegradation process took place in an irradiation chamber using $166-\mathrm{W}$ fluorescent lamps (see emission spectra of lamp together with absorption of QTX in Figure 1). The temperature was kept at $25{ }^{\circ} \mathrm{C}$ to avoid thermal degradation. For the identification and quantification of the generated products,

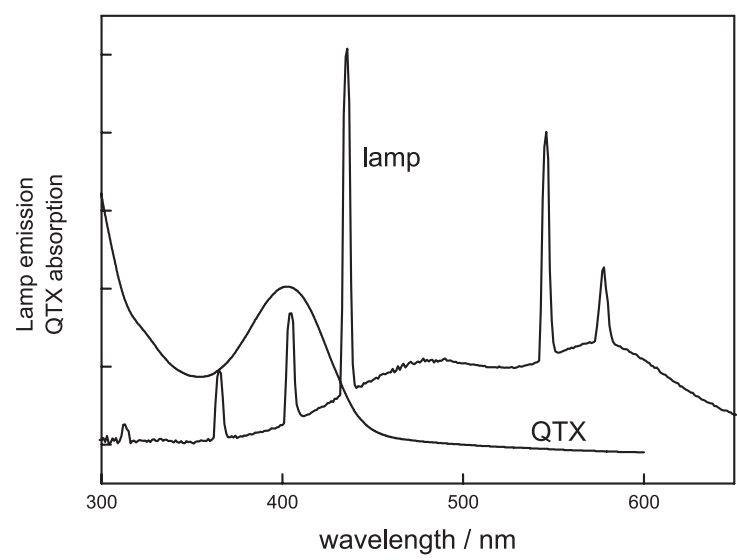

Figure 1. Emission spectrum of the lamp and absorption spectrum of QTX in aqueous solution.

aliquots were withdrawn from the reaction flasks at different times and analysed.

\section{High performance liquid chromatography (HPLC)}

After $160 \mathrm{~h}$ of irradiation, the QTX samples were preconcentrated by vacuum evaporation in a Savant/Speedvac system.

Degradation products were determined injecting $20 \mu \mathrm{L}$ samples in a Waters 2695 HPLC system with a Waters 2996 photodiode array detector. A C-18 $3.5 \mu \mathrm{m}$ $4.6 \times 75 \mathrm{~mm}$ column (Symmetry) was used at $30^{\circ} \mathrm{C}$, using methanol:water (70:30) as the mobile phase at a flow rate of $0.5 \mathrm{~mL} \mathrm{~min}^{-1}$.

The HPLC system was coupled to an ESI-MS (electrospray ionization mass spectrometer, Waters ZQ 2000). The operating conditions were optimised in order to achieve maximum sensitivity values: i.e., capillary voltage of $3 \mathrm{kV}$, the source temperature $100{ }^{\circ} \mathrm{C}$, the desolvation temperature $350{ }^{\circ} \mathrm{C}$, and desolvation gas flow $350 \mathrm{~L} \mathrm{~h}^{-1}$.

\section{Results and Discussion}

Figure 2A shows the spectra of an irradiated QTX $1.0 \times 10^{-4} \mathrm{~mol} \mathrm{~L}^{-1}$ aqueous solution. Before irradiation the dye presented bands at 273 and $402 \mathrm{~nm}$. There is an initial increase of the absorption of these bands up to the first $10 \mathrm{~h}$ which can be seen clearly in Figure 2. After this initial period, the intensity of these bands decreases and a new band at 320-330 nm, typical of oxidized QTX, starts to grow-in (Figure 2B). This band can be associated to that found by Kinart et al. ${ }^{11}$ at $310 \mathrm{~nm}$, during the electro-oxidation and electro-reduction of QTX in aqueous solution. The band was assigned to the presence of a sulfoxide, which is formed during the QTX electrooxidation. ${ }^{11}$ 


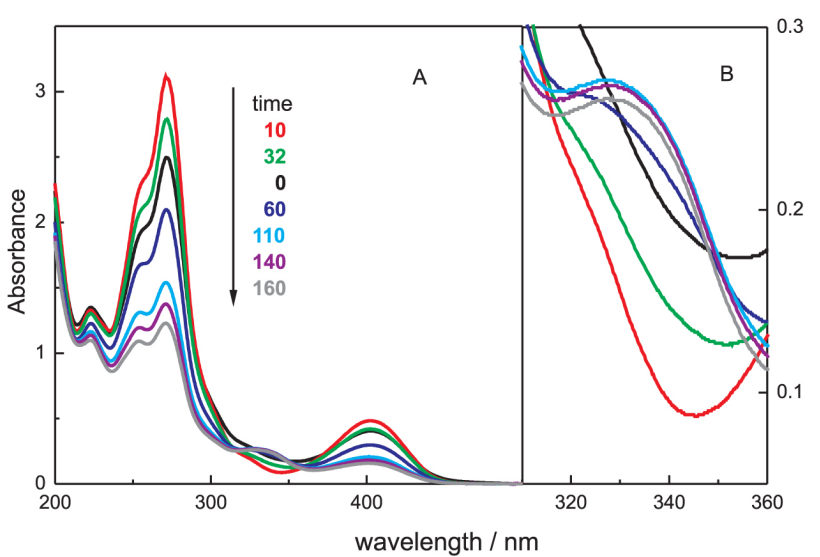

Figure 2. (A) Absorption spectra of QTX $1.0 \times 10^{-4} \mathrm{~mol} \mathrm{~L}^{-1}$ as a function of irradiation time. (B) blow-up of the 320-340 $\mathrm{nm}$ region.

As can be seen in Figure 3 the profiles of the bands at 273 and $402 \mathrm{~nm}$ are similar, and inverse to that of the $320 \mathrm{~nm}$ absorption, suggesting that the formation of the latter corresponds to a compound formed in the degradation of the original compound.

Therefore, the degradation process could be followed by the changes in the band intensity at $402 \mathrm{~nm}$, as well as by the appearance of the 320-330 $\mathrm{nm}$ band, in function of irradiation time for different QTX concentrations (Figure 4). The times necessary to decompose $25 \%$ of the original compound $\left(\mathrm{t}_{1 / 4}\right)$ for different initial concentrations QTX can be estimated from the decays in Figure 4 and are shown in Table 1. The faster decomposition at higher concentrations can be assigned to the presence of more chromophores which will absorb more light, therefore accelerating the photosensitization.

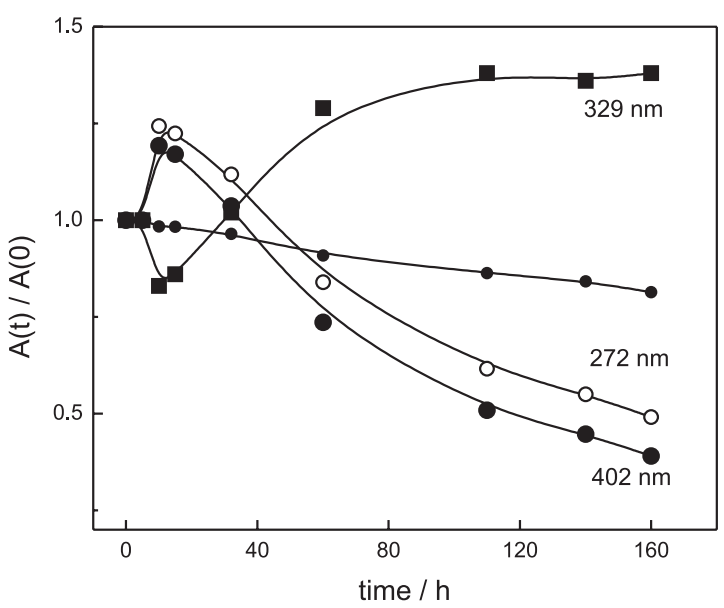

Figure 3. Time evolution of the absorbance of irradiated QTX $1.0 \times 10^{-4} \mathrm{~mol} \mathrm{~L}^{-1}$ at various wavelengths.

Table 1. Irradiation times necessary to photodecompose $25 \%$ of QTX

\begin{tabular}{lcccc}
\hline$[\mathrm{QTX}] /\left(\mathrm{mol} \mathrm{L}^{-1}\right)$ & $3 \times 10^{-5}$ & $5 \times 10^{-5}$ & $7 \times 10^{-5}$ & $1 \times 10^{-4}$ \\
\hline $\mathrm{t}_{1 / 4} / \mathrm{h}$ & 175 & 126 & 52 & 52 \\
\hline
\end{tabular}

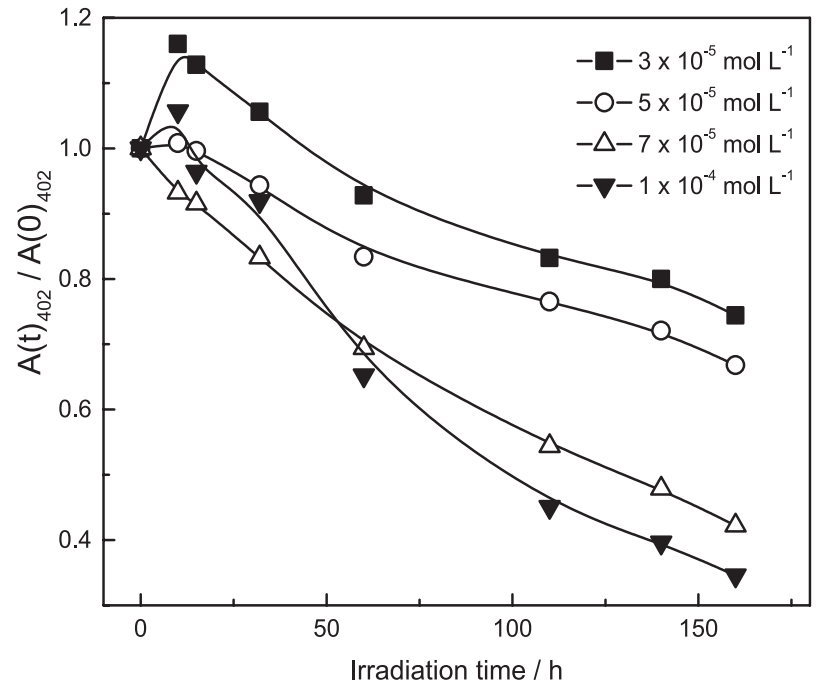

Figure 4. Relative absorption intensities of the 402-nm band during irradiation of QTX at different concentrations. $\mathrm{A}_{0}$ and $\mathrm{A}_{\mathrm{t}}$ are the absorbance at zero initial and t times, respectively.

In the presence of oxygen, the mechanism of dye degradation involves the participation of reactive oxygen species. From the photochemical point of view, there are two possible mechanisms for the interaction of the excited sensitizer with oxygen. ${ }^{7,16,17}$

(i) Energy transfer, which leads to the formation of singlet oxygen:

Dye + h $v \rightarrow \rightarrow{ }^{3}$ Dye $^{*}$

${ }^{3} \mathrm{Dye}^{*}+{ }^{3} \mathrm{O}_{2} \rightarrow$ Dye $+{ }^{1} \mathrm{O}_{2}$

Dye $+{ }^{1} \mathrm{O}_{2} \stackrel{\text { deactivation }}{\longrightarrow}$ Dye $+{ }^{3} \mathrm{O}_{2}$

Dye $+{ }^{1} \mathrm{O}_{2} \rightarrow$ Product

(ii) Electron transfer from the excited dye to oxygen, which leads to the formation of the superoxide anion $\left(\mathrm{O}_{2}{ }^{--}\right)$ and a dye radical cation:

Dye $+\mathrm{h} v \rightarrow \rightarrow{ }^{3}$ Dye $^{*}$

${ }^{3} \mathrm{Dye}^{*}+{ }^{3} \mathrm{O}_{2} \rightarrow \mathrm{Dye}^{\bullet+}+\mathrm{O}_{2}^{\cdot-}$

Dye ${ }^{\bullet+}+\mathrm{O}_{2}^{\cdot-} \rightarrow$ Products

Determination of photoproducts obtained from QTX degradation

Photoproducts obtained from QTX degradation in aqueous solution were investigated using HPLC/ESI-MS. Figure 5 shows the chromatogram and mass spectrum of 

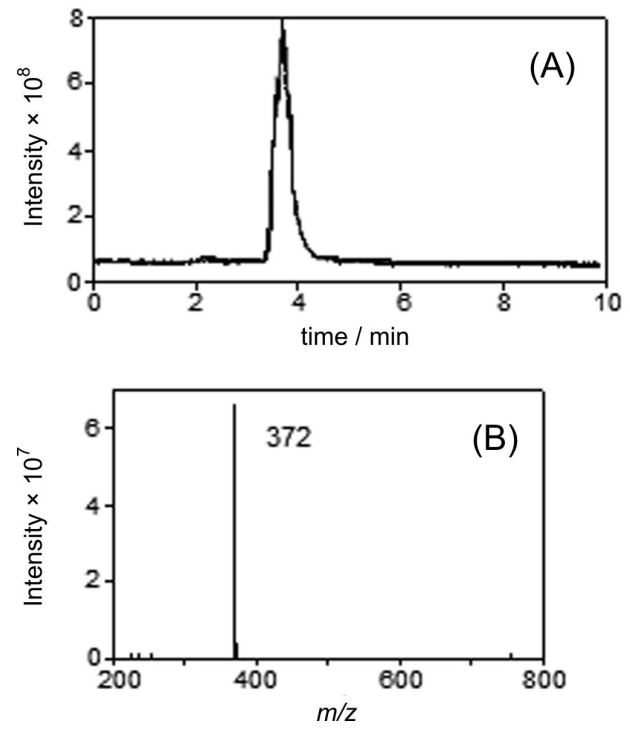

Figure 5. (A) HPLC/ESI-MS chromatogram and (B) ESI-MS spectrum of QTX before irradiation.

QTX before irradiation. The peak at $\mathrm{m} / \mathrm{z}, 372$ corresponds to unreacted QTX.

New peaks can be observed in the chromatogram after irradiation of QTX in aqueous solution for $160 \mathrm{~h}$ (Figure 6A). These peaks appear at $\mathrm{m} / \mathrm{z} 388,420$ and 270 and correspond to photoproducts of the QTX degradation and can be identified by their mass spectra (Figure 6B and $6 \mathrm{C})$.

The compound corresponding to the peak at $\mathrm{m} / \mathrm{z} 388$ arises from the addition of an oxygen atom to QTX, forming a sulfoxide (Scheme 2). Kinart et al. ${ }^{11}$ suggested the formation of the same species during the electro-oxidation and electro-reduction of QTX in aqueous solution.

On the other hand, the photoproduct at $\mathrm{m} / \mathrm{z} 420$ was assigned to the formation of a sulfone simultaneously to the introduction of a hydroxyl in the methyl group. In this case, the oxidation process involves the insertion of singlet oxygen (sensitized by triplet QTX) in a C-H bond, followed by the cleavage of the peroxide and abstraction of a hydrogen from the solvent. (Scheme 3).

Sulfoxide and sulfone derivates from thioxanthone were also observed by Kissinger et al. during an electrochemistry
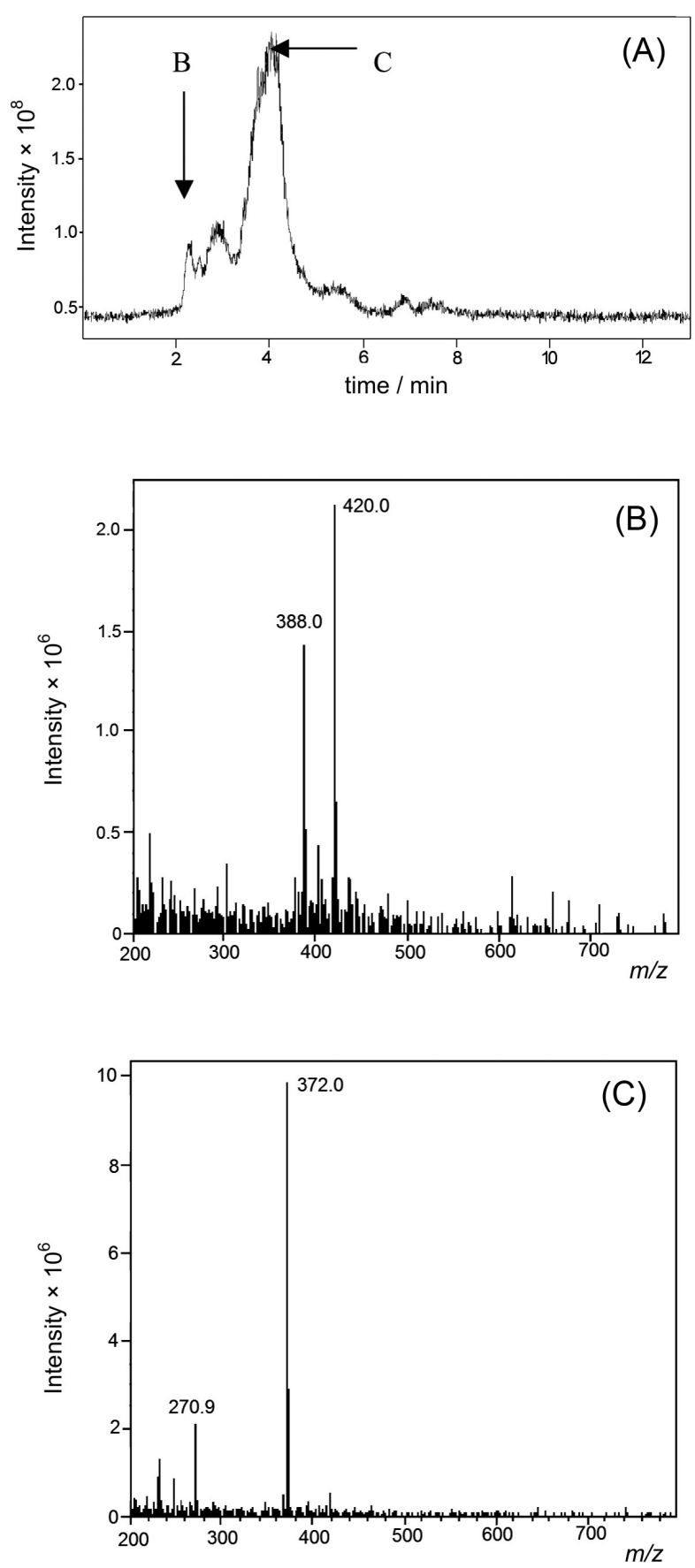

Figure 6. (A) HPLC/ESI-MS chromatogram and ESI-MS spectra of peaks $\mathrm{B}$ and C of QTX irradiated for $160 \mathrm{~h}$.<smiles>Cc1c(OCC(O)C[N+](C)(C)C)cc2c(=O)c3ccccc3sc2c1C</smiles>

$(m / z 372)$<smiles>Cc1ccc2c(c1)S(=O)c1c(cc(OCC(O)C[N+](C)(C)C)c(C)c1C)C2=O</smiles>

$(\mathrm{m} / \mathrm{z} 388)$

Scheme 2. Structure of the $\mathrm{m} / \mathrm{z} 388$ photoproduct. 
<smiles>Cc1c(OCC(O)C[N+](C)(C)C)cc2c(=O)c3ccccc3sc2c1C</smiles><smiles>C#C[N+](C)(C)CC(O)COc1cc2c(c(CO)c1C)S(=O)(=O)c1ccccc1C2=O</smiles><smiles>Cc1c(OCC(O)C[N+](C)(C)[OH2+])cc2c(c1C[O-])S(=O)(=O)c1ccccc1C2=O</smiles>
$(m / z 420)$

Scheme 3. Formation of the $m / z, 420$ photoproduct.<smiles>Cc1c(OCC(O)C[N+](C)(C)O)cc2c(=O)c3ccccc3sc2c1C</smiles>

$(m / z 372)$<smiles>COc1cc2c(=O)c3ccccc3sc2c(C)c1C</smiles>

$(m / z 270)$

Scheme 4. Formation of the $m / z 270$ photoproduct.

study of the dye. These compounds were observed at potentials of 1.67 and $2.08 \mathrm{~V}$, respectively.

The peak at $m / z 270$ suggests that an excited species of oxygen may react with QTX by abstracting a hydrogen atom from the carbon bonded to the hydroxyl group, followed by the release of the amino group and further rearrangements leading to a methoxy group on the thioxanthone ring (Scheme 4).

\section{Conclusions}

Ground state absorption spectrum of QTX showed bands at $273 \mathrm{~nm}$ and $402 \mathrm{~nm}$. After $160 \mathrm{~h}$ of irradiation,<smiles>Cc1c(OCC(O)C[N+](C)(C)C)cc2c(=O)c3ccccc3sc2c1C</smiles><smiles>C=CC[N+]12CCC(CC1)N2CC(=C)OCc1cc2c(=O)c3ccccc3sc2c(C)c1C</smiles>

the absorption intensity at $402 \mathrm{~nm}$ and $273 \mathrm{~nm}$ decreases together with the appearance of a band around 310-340 nm, typical of oxidized QTX.

New peaks due to the photodegradation of QTX after $160 \mathrm{~h}$ irradiation were observed by HPLC/ESI-MS analysis. An identification of these products (including sulfoxides and sulfones) was performed using their mass spectra.

\section{Acknowledgments}

Financial support from FAPESP (Proc. 2007/08515-9 and 05/03692-4) and CNPq (Proc. 471310/2006-9) is gratefully acknowledged. The authors thank Prof. Dr. 
Roberto Berlinck for performing the mass spectroscopy measurements.

\section{References}

1. Encinas, M. V.; Rufs, A. M.; Corrales, T.; Catalina, F.; Peinado, C.; Schmitt, C. C.; Neumann, M. G.; Allen, N. S.; Polymer 2002, 43, 3909.

2. Roffey, C.; Photodegradation of Reactive Species for UV-Curing, Wiley: Sussex, UK, 1997.

3. Neumann, M. G.; Gehlen, M. H.; Allen, N. S.; Corrales, T.; Peinado, C.; Catalina, F.; J. Chem. Soc. Faraday Trans. 1997, 93, 1517.

4. Ferreira, G. C.; Schmitt, C. C.; Neumann, M. G.; J. Braz. Chem. Soc. 2006, 17, 905.

5. Yates, S. F.; Schuster, G. B.; J. Org. Chem. 1984, 49, 3349.

6. Hayakawa, T.; Horie, K.; Dent. Mater. 1992, 8, 351.

7. Onu, A.; Palamaru, M.; Tutivan, E.; Ciobanu, C.; Polym. Deg. Stab. 1998, 60, 465.

8. Boloev, T. B.; Dobomatov, K. H.; Kalantarov, J.; Int. J. Polym. Mater. 1993, 19, 223.

9. Allen, N. S.; Polym. Deg. Stab. 1994, 44, 357.

10. Neumann, M. G.; Schmitt, C. C.; Goi, B. E.; J. Appl. Polym. Sci. 2010, 115, 1283.
11. Kinart, W. J.; Skowronski, R.; Turala, L.; Dawid, W.; Omakowska, J.; Kinart, C. M.; J. Electroanal. Chem. 1990, 294, 293.

12. Gorner, H.; Photochem. Photobiol. Sci. 2008, 7, 371.

13. Rauf, M. A.; Ashraf, S. S.; Alhadrami, S.; Dyes Pigm. 2005, 66, 197.

14. Abdullah, F. H.; Rauf, M. A.; Ashraf, S. S.; Dyes Pigm. 2007, 72, 349.

15. Rauf, M. A.; Ashraf, S. S.; J. Hazard. Mater. 2009, 166, 6.

16. Gangra, N.; Frank, A. T.; Gendre, O. L.; Sawwan, N.; Aebisher, D.; Liebman, J. F.; Houk, K. N.; Greer, A.; Gao, R.; Tetrahedron 2006, 62, 10771.

17. Chen, P.; Li, J.; Qian, Z.; Zheng, D.; Okasaki, T.; Hayami, M.; Dyes Pigm. 1998, 37, 213.

18. Ranby, B.; Rabek, J. F.; Photodegradation, Photo-oxidation and Photostabilization of Polymers, Wiley: London, 1975, ch. 5.

19. Kissinger, P. T.; Holt, P. T.; Reilley, C. N.; J. Electroanal. Chem. 1971, 33, 1.

Submitted: May 27, 2010

Published online: September 14, 2010

FAPESP has sponsored the publication of this article. 